\title{
Caffeine consumption and Parkinson's disease: a mini-review of current evidence
}

\author{
Consumo de cafeína e doença de Parkinson: uma mini- \\ revisão das evidências recentes
}

\section{Consumo de cafeína en la enfermedad de Parkinson: una mini revisión de la evidencia}

\section{Daniella Balduino Victorino ${ }^{1}$, Marcia Jonathas Guimarães-Marques ${ }^{1}$, Astrid Nehlig ${ }^{2}$}

1.Discipline of Neuroscience, Department of Neurology and Neurosurgery, Universidade Federal de São Paulo, Escola Paulista de Medicina, São Paulo-SP, Brazil. Institut du Cerveau (ICM), Sorbonne Université, Paris, France.

2.INSERM U1129, Paris/Strasbourg, France.

\begin{abstract}
Resumo
Na ausência de tratamentos eficientes para a doença de Parkinson (DP), a pesquisa se concentrou na identificação de fatores ambientais potenciais, cuja modulação pode prevenir ou retardar a progressão deste distúrbio neurodegenerativo. Evidências epidemiológicas convincentes sugerem que o consumo de cafeína está inversamente associado ao risco de desenvolver DP. Outros achados experimentais demonstraram que a cafeína, ao direcionar particularmente os receptores de adenosina $A 2 A\left(A_{2 A} R\right)$, protegeu os modelos animais de DP contra a perda de neurônios dopaminérgicos. A ação antagônica da cafeína nos receptores de adenosina não apenas desacelerou a neurodegeneração relacionada à $\mathrm{DP}$, mas também melhorou os sintomas motores e não motores da DP em modelos animais. Aqui, revisamos os mecanismos de ação potenciais pelos quais a cafeína pode desempenhar um papel na redução do risco de DP. Também revisamos as evidências atuais dos benefícios do consumo de cafeína nos sintomas motores e não motores da DP. Finalmente, apontamos como esses achados promissores podem levar à identificação de novas abordagens para o tratamento eficaz da DP. Unitermos. cafeína; Doença de Parkinson; distúrbios neurodegenerativos
\end{abstract}

\begin{abstract}
In the absence of efficient disease-modifying treatments for Parkinson's disease (PD), research has focused on identifying potential environmental factors whose modulation may prevent or slow the progression of this neurodegenerative disorder. Compelling epidemiological evidence suggests that caffeine consumption is inversely associated with the risk of developing PD. Further experimental findings demonstrated that caffeine, by particularly targeting adenosine $A_{2 A}\left(A_{2 A} R\right)$ receptors, protected PD animal models against the loss of dopaminergic neurons. The antagonistic action of caffeine on adenosine receptors not only slowed PD-related neurodegeneration, but also improved motor and nonmotor symptoms of PD in animal models. Here, we review the potential action mechanisms by which caffeine might play a role in reducing the risk of PD. We also review current evidence of the benefits of caffeine consumption in motor and nonmotor symptoms of PD. Finally, we point out how these promising findings could lead to the identification of new approaches for effective treatment of PD.
\end{abstract}

Keywords. Caffeine; Parkinson's disease; neurodegenerative disorder

\section{Resumen}

En ausencia de tratamientos eficientes para la enfermedad de Parkinson (EP), la investigación se ha centrado en identificar posibles factores ambientales cuya modulación puede prevenir o retardar la progresión de este trastorno neurodegenerativo. Evidencias epidemiológicas convincentes sugieren que el consumo de cafeína está inversamente asociado con el riesgo de 
desarrollar EP. Otros hallazgos experimentales demostraron que la cafeína, al dirigirse particularmente a los receptores de adenosina $A 2 A\left(A_{2 A} R\right)$, protegería a los modelos animales con EP contra la pérdida de neuronas dopaminérgicas. La acción antagonista de la cafeína en los receptores de adenosina no solo retardo la neurodegeneración relacionada con la EP, sino que también mejoró los síntomas motores y no motores de la EP en modelos animales. Aquí, revisamos los posibles mecanismos de acción por los cuales la cafeína podría desempeñar un papel en la reducción del riesgo de EP. También revisamos las evidencia actuales de los beneficios del consumo de cafeína sobre los síntomas motores y no motores de la EP. Finalmente, señalamos cómo estos interesantes hallazgos podrían conducir a la identificación de nuevos enfoques para el tratamiento eficaz de la EP.

Palabras clave. cafeína; Enfermedad de Parkinson; trastorno neurodegenerativo

Trabalho desenvolvido para o curso "Neurociência em Pauta" ("Neuroscience at hand"), ministrado pelo Programa de Pós-Graduação em Neurologia/Neurociências da Escola Paulista de Medicina, Unifesp, São Paulo-SP, Brasil.

\section{INTRODUCTION}

Over the last years, around 165 million 60-kilogram bags of coffee were globally consumed (https://www.statista.com/statistics/292595/global-coffee-consumption/), which makes coffee one of the most widely consumed beverages worldwide (FoodData Central- USDA). Coffee contains more than a thousand bioactive compounds, including the psychoactive agent caffeine (FoodData Central- USDA). Its composition varies depending on the type of bean (e.g., Arabica and Robusta) and how it is produced (e.g., the level of roasting and grind setting) and prepared for drinking (e.g., filter coffee, dripfilter, plunger coffee, and espresso machine) (FoodData Central- USDA). Besides coffee, caffeine also naturally occurs in a variety of plants, such as cacao beans, tea leaves, and guarana berries (FoodData Central- USDA) ${ }^{1}$. Synthetic caffeine can also be added to food, beverages, and 
medications, such as soft drinks, energy drinks, and painkillers (FoodData Central- USDA).

Caffeine is by far the most studied biologically active compound of coffee. Compelling evidence supports beneficial effects of caffeine consumption on both brain health and disease $^{2}$. Low to moderate doses of caffeine (50-200 mg) enhance alertness, reduce reaction time, and promote good mood $^{2}$. Drinking moderate amounts of coffee regularly is also associated with a lower risk of all-cause death, as well as with a reduced risk of developing neurological disorders, such as Parkinson's disease (PD) ${ }^{2}$.

Parkinson's disease is a neurodegenerative disorder characterized by the degeneration of dopaminergic neurons in the substantia nigra pars compacta (SNc) ${ }^{3}$. This disorder is the fastest growing in prevalence, disability, and deaths. In fact, the number of persons with PD worldwide has more than doubled over the past decades (from about 2.5 million people in 1990 to up to 6.1 million people in 2016) and it is expected to double again by $2050^{3}$. Yet, no diseasemodifying therapies capable of stopping or slowing PD progression have been developed ${ }^{3}$.

In this study, we provide a mini-review of the potential action mechanisms by which caffeine may reduce the risk of developing PD. We also provide current evidence of the benefits of caffeine consumption in motor and nonmotor symptoms of PD. Finally, we discuss how these findings may open novel avenues for advancing therapeutic strategies in PD. 


\section{Caffeine metabolism}

Chemically, caffeine is a methylxanthine $(1,3,7-$ trimethylxanthine). The absorption of caffeine takes place mainly in the stomach and small intestine, and it is almost completely absorbed within 45 minutes $^{4}$. After ingestion, caffeine reaches peak plasma concentrations of 0.25 to $2 \mathrm{mg} / \mathrm{l}$ (or approximately 1 to $10 \mu \mathrm{M}$ ) within 15 to 120 minutes ${ }^{4}$. Given caffeine's lipophilicity, it readily crosses the blood-brain barrier and reaches brain concentrations up to $70 \mu \mathrm{M}$ after moderate intake levels ${ }^{1}$. Most neurobehavioral effects of caffeine are bell-shaped: while low to moderate caffeine consumption produces beneficial effects, high intake levels may lead to deleterious outcomes ${ }^{1}$.

Caffeine is metabolized by the liver cytochrome P-450 (CYP) oxidase system, wherein CYP1A2 activity accounts for more than $90 \%$ of caffeine metabolism ${ }^{4}$. Caffeine is primarily metabolized to paraxanthine (1,7-dimethylxanthine), theobromine (3,7-dimethylxanthine) and theophylline (1,3dimethyl-7H-purine-2,6-dione $)^{4}$. Paraxanthine is the major metabolite of caffeine (70-80\%) in humans. It shows halflife similar to that of caffeine (caffeine's half-life is highly variable among subjects, but it usually ranges from 2.5 to 5 hours in healthy individuals), whereas theobromine and theophylline show longer half-lives ${ }^{4}$. Paraxanthine also reaches peak plasma concentrations 10 -fold larger than those of theophylline or theobromine. Only 1 to $5 \%$ of caffeine is excreted as unchanged (caffeine is nearly entirely 
reabsorbed by the renal tubule), thereby explaining the slow clearance of its metabolites ${ }^{4}$.

Caffeine metabolism was found to be affected by various physiological and pharmacological factors ${ }^{4}$. For example, smoking decreases caffeine half-life by up to $50 \%$, whereas oral contraceptives may double it ${ }^{4}$. Pregnancy also greatly decreases caffeine clearance and increases its halflife, particularly in the third trimester, wherein caffeine halflife can be up to 15 hours ${ }^{4}$.

\section{Modulation of adenosine receptors in brain physiology and Parkinson's disease pathogenesis}

Caffeine is a competitive, non-selective antagonist of adenosine receptors, which belongs to the G-protein-coupled receptor (GPCR) family ${ }^{5}$. Three classes have been used to classify these receptors: $A_{1}, A_{2}$, and $A_{3}{ }^{5}$. Adenosine $A_{1}\left(A_{1} R\right)$ and $A_{2 A}\left(A_{2 A} R\right)$ receptors are the commonest types of adenosine receptors found in the brain ${ }^{6}$, wherein both $A_{1} R$ and $A_{2 A} R$ are mostly located in synapses, particularly in the excitatory (glutamatergic) ones ${ }^{6}$. The $A_{1} R$ is highly expressed in the cortex, hippocampus, and cerebellum, whereas $A_{2 A} R$ is primarily found in the basal ganglia, although it can also be found at low levels in other brain regions, such as the hippocampus and cortex ${ }^{6}$. The consumption of 3 to 4 cups of coffee per day is sufficient to occupy nearly $50 \%$ of $A_{1} R$ and $A_{2 A} R$ for at least several hours ${ }^{1}$.

While $A_{2 A} R$ is mostly coupled to $G_{s}$ proteins, $A_{1} R$ is primarily coupled to $\mathrm{G}_{\mathrm{i} / \mathrm{o}}$ proteins, whose activation leads to 
excitatory and inhibitory effects, respectively. For example, the activation of $A_{2 A} R$ by extracellular adenosine increases gamma-aminobutyric acid (GABA) uptake by astrocytes, which decreases tonic GABAergic inhibition and enhances excitatory tonus ${ }^{6}$. On the other hand, $A_{1} R$ activation inhibits GABA transport into astrocytes, thereby increasing extracellular concentrations of GABA and depressing excitatory drive ${ }^{6}$. In neurons, postsynaptic activation of $A_{1} R$ inhibits $\mathrm{N}$-methyl-D-aspartate (NMDA) receptor-mediated currents $^{6}$, and it may also lead to membrane hyperpolarization via G-protein-dependent activation of inwardly rectifying $\mathrm{K}^{+}$channels (GIRKs) ${ }^{6}$. Conversely, the presynaptic activation of $A_{1} R$ inhibits the release of several neurotransmitters (e.g., glutamate, GABA, acetylcholine, and monoamines) probably via G-protein-coupled inhibition of $\mathrm{Ca}^{2+}$ channels at the nerve terminals ${ }^{6}$. In general, the most prominent inhibitory effect mediated by adenosine is at the level of excitatory synapses, whereas adenosinemediated inhibition of GABAergic transmission is less frequently observed. Therefore, the net effect of adenosine receptor activation is to decrease excitability throughout the brain $^{2}$. This is consistent with findings of caffeine-induced EEG changes during arousal, in which caffeine, by antagonizing the effects of endogenous adenosine, increases neuronal firing rate ${ }^{2}$.

Caffeine's ability to modulate dopaminergic neurotransmission in basal ganglia by targeting $A_{2 A} R$ has attracted considerable attention over the last decades, 
particularly because of its potential as a symptomatic therapy for $\mathrm{PD}^{7}$. Increasing evidence indicates that the overactivation of $A_{2 A} R$ due to increased extracellular adenosine levels by ATP release may contribute to the pathogenesis of PD. In fact, pharmacological and genetic blockade of $A_{2 A} R$ prevents PD-associated neurodegeneration and motor dysfunction in experimental models ${ }^{7}$. This increase in extracellular adenosine is accompanied by increased levels of glutamate release from presynaptic neurons and astrocytes, thereby contributing to glutamatemediated excitotoxic damage to dopaminergic neurons ${ }^{7}$. The overactivation of $A_{2 A} R$ was also associated with increased levels of pro-inflammatory cytokines and activated microglia, which have been shown to be involved in PD neurodegeneration?. Such findings demonstrate the functional role of endogenous adenosine via $A_{2 A} R$ activation in modulating neuroinflammation and brain injury. They also suggest that the antagonism of $A_{2 A} R$ may be a promising strategy in PD.

\section{Neuroprotective benefits of caffeine in Parkinson's disease}

Coffee and caffeine consumption has long been associated with reduced risk of developing PD. For example, a 30-year follow up study involving 8004 Japanese-American male individuals (aged 45-68 years) found that subjects who consumed 3.5 cups of coffee or more per day had a significantly lower risk of developing PD than subjects who 
were non-drinkers of coffee $^{8}$. A further study involving 47,351 men and 88,565 women also linked moderate consumption of coffee with reduced risk of developing $\mathrm{PD}^{9}$. Interestingly, a U-shaped association between coffee consumption and risk of PD was found in the female subgroup, wherein women who reported drinking 1 to 3 cups of coffee/day had the lowest risk of developing PD ${ }^{9}$. More recently, a meta-analysis involving 13 cohort studies showed that caffeine consumption was significantly associated with a lower risk of developing PD in the healthy cohort, as well as with a lower rate of PD progression in the PD cohort ${ }^{10}$. Since the consumption of decaffeinated coffee was not significantly linked to a lower risk of $\mathrm{PD}^{9}$, the inverse association between coffee drinking and PD was particularly attributable to caffeine itself rather than to other coffee components.

The potential neuroprotective effects of caffeine are further supported by mounting evidence from experimental studies, particularly in neurotoxin-induced PD models. For example, the administration of caffeine protected against 1methyl-4-phenyl-1,2,3,6-tetrahydropyridine (MPTP) induced loss of nigrostriatal dopaminergic neurons in PD animal models ${ }^{11,12}$. This effect was mimicked by several $A_{2 A} R$ antagonists, which suggest that caffeine may attenuate MPTP-induced neurotoxicity by $A_{2 A} R$ blockade ${ }^{12}$. Importantly, caffeine was also found to protect against the loss of dopaminergic neurons in a chronic progressive rat model of MPTP-induced PD even when treatment was initiated 1 or 3 weeks after the beginning of MPTP infusions ${ }^{11}$. Similar 
neuroprotective effects of caffeine were also observed in 6hydroxydopamine (6-OHDA)-lesioned rats $^{13}$, as well as in rats chronically exposed to pesticides ${ }^{14}$.

The neuroprotective benefits of caffeine have also been observed in a-synuclein (a-Syn)-mediated pathology. A recent study showed that chronic caffeine consumption (at the levels regularly consumed by humans) attenuated a-Syn inclusion pathology in a mouse model of PD by attenuating a-Syn-induced apoptosis, microglial activation, and reactive astrogliosis in the striatum ${ }^{15}$. Findings from Yan and colleagues revealed that caffeine acts in synergy with eicosanoyl-5-hydroxytryptamide (EHT), a fatty acid derivative of serotonin found in coffee, to protect against neuronal damage and neuroinflammation in mouse models of a-synucleinopathy ${ }^{16}$. The coadministration of caffeine and EHT also improved behavioral performance in mice better than each treatment alone ${ }^{16}$. Such neuroprotective effects of caffeine and EHT were associated with increased methylation levels of brain protein phosphatase 2A (PP2A), a kinase involved in a-Syn dephosphorylation ${ }^{16}$.

Caffeine analogues have also been shown to protect dopaminergic nigrostriatal neurons against neurodegeneration by potently inhibiting monoamine oxidases (MAOs), particularly monoamine oxidase B (MAO$B)$. In fact, the modulation of MAO-B activity by the caffeine analogue 8-(3-chlorostyryl)caffeine (CSC) was found to attenuate neurotoxicity mediated by MPTP ${ }^{17}$, as well as to rescue 6-OHDA-induced motor deficits in experimental 
models of $\mathrm{PD}^{18}$. This modulatory effect seemed to be independent of its well-established antagonistic action on $\mathrm{A}_{2 \mathrm{~A}} \mathrm{R}^{18}$, although $\mathrm{CSC}$, when administered in combination with other antagonists, was found to be more effective in ameliorating motor deficits in PD animal models ${ }^{17}$.

The production of pro-inflammatory-related molecules was also found to be modulated by caffeine consumption. For example, interleukin $1 \beta$ (IL-1 $\beta$ ) and tumor necrosis factor a (TNF-a), which may be among the major factors involved in neuroinflammation, showed lower levels of immunoreactivity in the SNc and striatum of 6-OHDA-lesioned rats treated with either 10 or $20 \mathrm{mg} / \mathrm{kg}$ caffeine for 2 weeks than in those of untreated 6-OHDA-lesioned rats ${ }^{13}$. A better understanding of the potential mechanisms by which caffeine (and its analogues) modulates survival of dopaminergic neurons as well as neuroinflammation may lead to the identification of novel drug targets and strategies for PD.

\section{Benefits of Caffeine in motor symptoms of Parkinson's disease}

Caffeine consumption seems to play a beneficial role in improving parkinsonian motor deficits. A preliminary 6-week open-label pilot study showed that caffeine twice daily improved motor symptoms in PD patients ${ }^{19}$. A further 6-week randomized, placebo-controlled, double-blind clinical trial involving 61 patients confirmed the potential motor benefits of caffeine in subjects with $\mathrm{PD}^{20}$. A more recent crosssectional study involving 196 early-stage, treatment-naïve 
PD patients found that coffee drinkers had lower Unified Parkinson's Disease Rating Scale (UPDRS) motor scores than non-coffee drinkers ${ }^{21}$. Consistent with these findings, preclinical studies also reported beneficial effects of coffee consumption on motor function in PD animal models. For example, 6-OHDA-lesioned rats treated with caffeine showed an increase in locomotor activity, as well a decrease in apomorphine-induced contralateral rotations when compared with untreated 6-OHDA-lesioned rats ${ }^{13}$.

Findings from clinical studies have pointed to an important role that caffeine may play in preventing levodopa-induced dyskinesia. Patients with PD who consumed more than 12 ounces of coffee per day had a lower risk of developing dyskinesia than those consuming less than 4 ounces of coffee per day ${ }^{22}$. A further multicenter casecontrol study involving 485 patients with PD found that levodopa-induced dyskinesia was inversely associated with coffee drinking ${ }^{23}$. A significant trend of decreasing risk of dyskinesia with increasing number of cups per day was also reported $^{23}$. These findings suggest that moderate consumption of caffeine may reduce the long-term risk of levodopa-induced dyskinesia in PD.

Despite promising data on the role of caffeine in PD risk and progression, whether an inverse relationship exists between caffeine consumption and PD remains inconclusive. A nested case-control study involving 476 PD patients and 2370 control subjects found no association between coffee consumption and $\mathrm{PD}^{24}$. In a more recent double-blind, 
multicenter, parallel-group, controlled trial involving 121 PD patients, Postuma et al reported no substantial change in motor parkinsonism severity in PD patients receiving caffeine $200 \mathrm{mg}$ twice daily for 6 months ${ }^{25}$. Genetic polymorphism, sex, and differential absorption, metabolism, or clearance of caffeine have been shown to influence the effects of caffeine on PD pathophysiology 26,27 , and thus may contribute to the inconsistent results reported in the literature. For example, plasma caffeine concentration was $76 \%$ lower in Leucine-rich repeat kinase 2 (LRRK2) mutation carriers with PD than those without $\mathrm{PD}^{26}$. Levels of caffeine metabolites (paraxanthine, theophylline, and 1-methylxanthine) were even lower in LRRK2 mutation carriers with PD than those without $\mathrm{PD}^{26}$. Angelopoulou et al detected a negative association between coffee drinking and risk of early- but not later-onset PD. Given that LRRK2 mutations are considered major causes of PD, and that early-onset PD is more likely to be genetic than later-onset PD, these studies highlight a potential role of gene-environment interactions in PD etiology. Further research on the inverse association between coffee consumption and PD should take into account a potential genetic role in individual responses to caffeine (and possibly to other adenosine receptor modulators). 
Benefits of Caffeine in nonmotor symptoms of

\section{Parkinson's disease}

Several observational studies have examined the relationship between drinking coffee and nonmotor symptoms in PD, such as mood disorders. In a crosssectional study involving 196 drug-naive patients with earlystage PD, it was found that the severity of symptoms such as social isolation, lack of motivation, anhedonia, and lack of pleasure was lower in coffee drinkers compared with nondrinkers ${ }^{21}$. An inverse association between coffee consumption and depressive mood in PD patients was also found ${ }^{21}$. On the other hand, in a double-blind, multicenter, parallel-group, controlled trial involving 121 PD patients, caffeine was associated with worse cognitive testing scores in PD patients who received $200 \mathrm{mg}$ caffeine twice daily compared with those who received placebo, although this may simply be a result of chance as it resulted from exploratory analysis (secondary outcomes) ${ }^{25}$.

The effects of caffeine consumption on excessive daytime somnolence (EDS) in PD patients have also been examined by previous studies. For example, it was reported that PD individuals with excessive somnolence who received up to $200 \mathrm{mg}$ caffeine twice daily over a 6-week period showed a borderline improvement in EDS compared to those who received matching placebo ${ }^{20}$. A recent $n-o f-1$ trial identified that espresso coffee intake exerted beneficial effects on daytime somnolence in some patients with PD, although care must be taken in the extrapolation of this 
finding to the general PD population with daytime somnolence ${ }^{28}$.

The consumption of caffeine has also been hypothesized to enhance cognitive performance, especially in the elderly. In animal models of PD, caffeine at the doses of 0.1 and 0.3 $\mathrm{mg} / \mathrm{kg}$ reversed cognitive impairments in MPTP-lesioned rats compared to control rats $^{29}$. Caffeine at doses up to 30.0 $\mathrm{mg} / \mathrm{kg}$ also reversed deficits in social recognition memory of reserpine-treated rats compared to control rats ${ }^{30}$. This modulatory effect is likely dependent on $A_{2 A} R$ signaling, since the $A_{2 A} R$ antagonist ZM241385 but not the $A_{1} R$ antagonist DPCPX was also found to rescue reserpine-induced deficits in social recognition memory ${ }^{30}$. Importantly, beneficial effects of caffeine (as well as $A_{2 A} R$ antagonist ZM241385) cannot be explained by improvements in locomotor activity of MPTPand reserpine-treated rats since no behavioral changes were observed in these animals ${ }^{29,30}$. Although the underlying mechanisms by which caffeine promotes benefits on cognitive performance need further elucidation, current evidence suggests that this psychostimulant agent and other $A_{2 A} R$ antagonists might play a role in symptomatic therapy for cognitive dysfunction in PD.

\section{CONCLUSION}

Based on the link between caffeine consumption and reduced risk of PD, we briefly discussed current evidence of potential protective effects of caffeine against neurodegeneration, as well as its benefits on motor and 
nonmotor symptoms of PD. The findings outlined here may have important clinical implications, especially because there are no disease-modifying therapies capable of stopping or slowing PD progression.

\section{ACKNOWLEDGEMENTS}

Our study is supported by the São Paulo Research Foundation (FAPESP) and National Council for Scientific and Technological Development (CNPq). DBV was funded by a postgraduate fellowship from FAPESP (\#2016/17746-3).

\section{REFERENCES}

1.Fredholm BB, Bättig K, Holmén J, Nehlig EEZ. Actions of caffeine in the brain with special reference to factors that contribute to its widespread use. Pharmacol Rev 1999;51:83-133. https://pharmrev.aspetjournals.org/content/51/1/83.long

2. Nehlig A. Effects of coffee/caffeine on brain health and disease: What should i tell my patients? Prac Neurol 2016;16:89-95. https://doi.org/10.1136/practneurol-2015-001162

3. Poewe W, Seppi K, Tanner CM, Halliday GM, Brundin P, Volkmann J, et al. Parkinson disease. Nat Rev Dis Prim 2017;3:1-21. https://doi.org/10.1038/nrdp.2017.13

4.Nehlig A. Interindividual differences in caffeine metabolism and factors driving caffeine consumption. Pharmacol Rev. 2018;70:384411. https://doi.org/10.1124/pr.117.014407

5. Fredholm BB, IJzerman AP, Jacobson $K A$, Linden J, Müller CE. International union of basic and clinical pharmacology. LXXXI. Nomenclature and classification of adenosine receptors - An update. Pharmacol Rev 2011;63:1-34. https://doi.org/10.1124/pr.110.003285 6. Borea PA, Gessi S, Merighi S, Vincenzi F, Varani K. Pharmacology of adenosine receptors: The state of the art. Physiol Rev 2018;98:1591625. https://doi.org/10.1152/physrev.00049.2017

7.Schwarzschild MA, Agnati L, Fuxe K, Chen JF, Morelli M. Targeting adenosine A2A receptors in Parkinson's disease. Trends Neurosci 2006;29:647-54. https://doi.org/10.1016/j.tins.2006.09.004

8. Ross GW, Abbott RD, Petrovitch H, Morens DM, Grandinetti A, Tung $\mathrm{KH}$, et al. Association of coffee and caffeine intake with the risk of Parkinson disease. J Am Med Assoc 2000;283:2674-9. https://doi.org/10.1001/jama.283.20.2674

9. Ascherio A, Zhang SM, Hernán MA, Kawachi I, Colditz GA, Speizer $\mathrm{FE}$, et al. Prospective study of caffeine consumption and risk of 
Parkinson's disease in men and women. Ann Neurol 2001;50:56-63. https://doi.org/10.1002/ana.1052

10.Hong CT, Chan L, Bai C-H. The Effect of Caffeine on the Risk and Progression of Parkinson's Disease: A Meta-Analysis. Nutrients 2020;12:1860. https://doi.org/10.3390/nu12061860

11.Sonsalla PK, Wong LY, Harris SL, Richardson JR, Khobahy I, Li W, et al. Delayed caffeine treatment prevents nigral dopamine neuron loss in a progressive rat model of Parkinson's disease. Exp Neurol 2012;234:482-7. https://doi.org/10.1016/j.expneurol.2012.01.022

12. Chen JF, Xu K, Petzer JP, Staal R, Xu YH, Beilstein $M$, et al. Neuroprotection by caffeine and $\mathrm{A}(2 \mathrm{~A})$ adenosine receptor inactivation in a model of Parkinson's disease. J Neurosci 2001;21:RC143. https://doi.org/10.1523/JNEUROSCI.21-10-j0001.2001

13. Machado-Filho JA, Correia AO, Montenegro ABA, Nobre MEP, Cerqueira GS, Neves KRT, et al. Caffeine neuroprotective effects on 6OHDA-lesioned rats are mediated by several factors, including proinflammatory cytokines and histone deacetylase inhibitions. Behav Brain Res 2014;264:116-25. https://doi.org/10.1016/j.bbr.2014.01.051

14. Kachroo A, Irizarry MC, Schwarzschild MA. Caffeine protects against combined paraquat and maneb-induced dopaminergic neuron degeneration. Exp Neurol 2010;223:657-61. https://doi.org/10.1016/j.expneurol.2010.02.007

15.Luan Y, Ren X, Zheng W, Zeng Z, Guo Y, Hou Z, et al. Chronic caffeine treatment protects against a-synucleinopathy by reestablishing autophagy activity in the mouse striatum. Front Neurosci 2018;12:301. https://doi.org/10.3389/fnins.2018.00301 16.Yan R, Zhang J, Park HJ, Park ES, Oh S, Zheng H, et al. Synergistic neuroprotection by coffee components eicosanoyl-5hydroxytryptamide and caffeine in models of Parkinson's disease and DLB. Proc Natl Acad Sci USA 2018;115:E12053-62. https://doi.org/10.1073/pnas.1813365115

17. Coccurello R, Breysse N, Amalric M. Simultaneous blockade of adenosine A2A and metabotropic glutamate mGlu5 receptors increase their efficacy in reversing Parkinsonian deficits in rats. Neuropsychopharmacol 2004;29:1451-61.

https://doi.org/10.1038/sj.npp.1300444

18.Chen JF, Steyn S, Staal R, Petzer JP, Xu K, Van Der Schyf CJ, et al. 8-(3-Chlorostyryl) caffeine may attenuate MPTP neurotoxicity through dual actions of monoamine oxidase inhibition and A2A receptor antagonism. J Biol Chem 2002;277:36040-4. https://doi.org/10.1074/jbc.M206830200

19.Altman RD, Lang AE, Postuma RB. Caffeine in Parkinson's disease: A pilot open-label, dose-escalation study. Mov Disord 2011;26:242731. https://doi.org/10.1002/mds.23873

20.Postuma RB, Lang AE, Munhoz RP, Charland K, Pelletier A, Moscovich $M$, et al. Caffeine for treatment of Parkinson disease: A randomized controlled trial. Neurology 2012;79:651-8. https://doi.org/10.1212/WNL.0b013e318263570d 
21. Cho BH, Choi SM, Kim JT, Kim BC. Association of Coffee Drinking and Non-motor Symptoms in Drug Naive, Early Stage Parkinson's Disease, Parkinsonism and Related Disorders. Parkinsonism Relat Disord 2018;50:42-47.

https://doi.org/10.1016/j.parkreldis.2018.02.016

22. Wills A-MA, Eberly S, Tennis M, Lang AE, Messing S, Togasaki D, et al. Caffeine consumption and risk of dyskinesia in CALM-PD. Mov Disord 2013;28:380-3. https://doi.org/10.1002/mds.25319

23. Nicoletti A, Zappia M, Mostile G, Arabia G, Nicoletti G, Quattrone A, et al. Coffee consumption and risk of levodopa-induced dyskinesia in Parkinson's disease: The FRAGAMP study. Mov Disord 2015;30:18546. https://doi.org/10.1002/mds.26459

24. Wirdefeldt K, Gatz M, Pawitan Y, Pedersen NL. Risk and protective factors for Parkinson's disease: A study in Swedish twins. Ann Neurol 2005;57:27-33. https://doi.org/10.1002/ana.20307

25.Postuma RB, Anang J, Pelletier A, Joseph L, Moscovich M, Grimes $D$, et al. Caffeine as symptomatic treatment for Parkinson disease (Café-PD). Neurology 2017; 89:1795-803.

https://doi.org/10.1212/WNL.0000000000004568

26. Crotty GF, Maciuca R, Macklin EA, Wang J, Montalban M, Davis SS, et al. Association of caffeine and related analytes with resistance to Parkinson disease among LRRK2 mutation carriers: A metabolomic study. Neurology 2020;95:e3428-37. https://doi.org/10.1212/WNL.0000000000010863

27.Fujimaki M, Saiki S, Li Y, Kaga N, Taka H, Hatano T, et al. Serum caffeine and metabolites are reliable biomarkers of early Parkinson disease. Neurology 2018;90:e404-11.

https://doi.org/10.1212/WNL.0000000000004888

28.Ferreira J], Mestre T, Guedes LC, Coelho M, Rosa MM, Santos AT, et al. Espresso Coffee for the Treatment of Somnolence in Parkinson's Disease: Results of n-of-1 Trials. Front Neurol 2016;7:1. https://doi.org/10.3389/fneur.2016.00027

29.Gevaerd MS, Takahashi RN, Silveira R, Da Cunha C. Caffeine reverses the memory disruption induced by intra-nigral MPTP-injection in rats. Brain Res Bull 2001;55:101-6. https://doi.org/10.1016/s03619230(01)00501-9

30.Prediger RDS, Da Cunha C, Takahashi RN. Antagonistic interaction between adenosine $\mathrm{A} 2 \mathrm{~A}$ and dopamine $\mathrm{D} 2$ receptors modulates the social recognition memory in reserpine-treated rats. Behav Pharmacol 2005; 16:209-18.

https://doi.org/10.1097/01.fbp.0000166825.62130.9a 